\title{
Opening a Discourse on Race Relations in New Zealand: The Fern and the Tiki Revisited
}

HARRY A. KERSEY Jr.

Florida Atlantic University

As we enter a new millennium the intellectual legacy of David P. Ausubel still resonates in Aotearoa-New Zealand. Some forty years after the American academic's provocative work The Fern and the Tiki first appeared in print it still evokes strong and mixed reactions from Pakeha and Maori alike. ${ }^{1}$ It certainly had a searing impact among a generation of New Zealanders who were in universities during the tumultuous civil rights dominated era of the 1960s and 1970s. Even those who have never read the book recognize the title, can name its author, and generally accord it some deference as a seminal work that should be read or reread.

Individuals as diverse as Sir Geoffrey Palmer, a former Prime Minister of New Zealand, and Maori activist Moana Jackson have indicated that the work provided a new focus on how Maori were treated by the dominant culture. Palmer is generally credited with revitalizing the Waitangi Tribunal by pushing through a 1985 amendment that gave it the right to hear retrospective claims dating back to 1840, thus opening up the field of modern treaty jurisprudence. When asked if he was familiar with Ausubel's work his immediate response was, 'Yes! The Fern and the Tiki. I do remember that book and I remember it caused such enormous controversy when it came out here ... I remember Ausubel's writing was certainly important. I was a student when it came out and obviously read it and it was factored into my consciousness.'2 Moana Jackson has a similar recollection: 'I was quite young then but I can remember the controversy around the book and I read it as a student and there was actually for me, and the other Maori students around me, nothing surprising in it at all. But for Pakeha people it was an attack on their myths, and what has happened in the intervening time is that Maori people have begun to critique those myths publicly, which they didn't do before, and even some Pakeha people are challenging the myths now. And I think his book is a landmark really and perhaps as a rule, whether this is the smallness of New Zealand or what, it often takes an outside person to say something that Maori people have been saying for years for others to react in some way.' ${ }^{3}$ 
Perhaps the best indicator of The Fern and the Tiki's persistence is the fact that it continues to be cited in the contemporary literature on race relations in New Zealand. During the 1990s no fewer than five books noted the American academic's contribution to opening a meaningful discourse on race relations. Some accorded it a mention only while others found the work ground breaking. In A Dream Deferred, published in 1990, David Pearson noted that 'Ausubel, a psychologist from the United States visiting these shores in the late 1950s, ruffled a great many local feathers when unmasking what he described as "a national self-delusion" about a recurring dream. Not the melting pot of the American Dream - New Zealand was too homogeneous for that - but a dream of one people resulting from Maori/Pakeha assimilation, with just the faintest tinge of other ethnic ingredients introduced from other sources. Hence New Zealanders had some portents of the flaws exposed in their multicultural or bicultural visions but still drew comfort from overseas comparisons. ${ }^{4}$ Nine years later Augie Fleras and Paul Spoonley, authors of Recalling Aotearoa, found that Ausubel 'drew attention to anomalies in New Zealand's race relations. Despite repeated references to racial harmony and equality, Ausubel discovered high levels of anti-Maori prejudice, lack of social acceptance and equal opportunity for Maori, and flagrant forms of discrimination in cinemas, banks, and hotels directed at Maori as either patrons or workers. ${ }^{5}$ The Maori jurist Edward T. Durie, a Justice of the High Court and Chairman of the Waitangi Tribunal, also admired the book. In a 1991 essay identifying various contributions to changing the climate of opinion about Maori treaty rights, he noted that 'It was a while ago, too, that Dr Ausubel wrote The Fern and the Tiki, drawing attention to the wide disparity in Maori and Pakeha perspectives' ${ }^{6}$ In a recent interview Durie reconfirmed his admiration for Ausubel's contribution in exposing antipodean delusions concerning race relations in the 1950s.

In 1993 the National Library of New Zealand/Te Puna Matauranga o Aotearoa initiated a project which sought to identify the literary building blocks of an identity for New Zealand. Some 200 prominent individuals were asked the question: 'What are the books that shaped New Zealand, and why?" ${ }^{7}$ Over 600 works were suggested and, when the list was winnowed down to 100 titles for display in an exhibition, The Fern and the Tiki was one of the books prominently featured. ${ }^{8}$ Yet despite this high acclaim, Ausubel's work was anything but well received by New Zealanders when it first appeared. There were two reasons. First, The Fern and the Tiki struck at the widely held Pakeha beliefs that relationships between the races were excellent, and that Maori, because they had the same legal rights, were treated the same as other citizens. At that time most white New Zealanders still accepted the tenets of what historian James Belich has called 'the race relations legend'. ${ }^{9}$ This worldview rested on the twin pillars of ethnocentric belief in European racial superiority 
and humanitarian commitment to the 'salvagability' of the Maori. By the early twentieth century this had led to an assimilationist agenda not unlike that contemporaneously being imposed on the American Indian tribes. Maori would ultimately disappear as a separate culture and become brown Englishmen or New Zealanders; the delusion was that Maori enjoyed equal political rights and economic opportunities as other citizens while undergoing this transformation. Second, Ausubel launched an exposé of a number of other cultural 'sacred cows' in New Zealand society. This drew such a bitter response from critics that it came close to vitiating the more significant aspects of his work.

During 2000, as a Fulbright Senior Scholar at the Alexander Turnbull Library, I commenced a comparative study of indigenous sovereignty issues in New Zealand and the United States. Because this was, and is, such a volatile topic, it was inevitable that Ausubel's mantle would be unwittingly inherited to a certain degree. Numerous persons asked half-facetiously if my own findings would create such a furore. Assuring everyone that this was not my intention, I nevertheless sensed a lingering Pakeha wariness of visiting American academics researching Maori issues. Therefore I set out to determine why this controversial scholar made such an impact during his limited sojourn in New Zealand.

The logical place to start was with the man himself. David P. Ausubel, a prototypical north-eastern liberal intellectual, was born in New York City in 1918. He received a BA at the University of Pennsylvania (1939), an MA in Experimental Psychology (1940) and a PhD in Developmental Psychology at Columbia University (1950). He also acquired an MD degree from Middlesex University (1943). Ausubel served as an assistant surgeon and psychiatric resident with the US Public Health service and worked in Germany in the medical treatment of displaced persons immediately after World War Two. He was then for a period a psychiatrist in Veterans Administration hospitals. He held professorships at various American universities, most notably the University of Illinois at Urbana-Champaign (1950-1966), and was professor of psychology, education, and medical education at the University of Toronto (1966-1968) before going to the City University of New York, where he headed the doctoral program in educational psychology until his retirement in 1975. Deeply involved with the Civil Rights movement, Ausubel undertook major studies on the learning problems of minority children, authoring 14 books and over 100 articles in a distinguished career. In 1976 he received the prestigious E.L. Thorndike Award from the American Psychological Association 'for distinguished psychological contributions to Education'. ${ }^{10}$ After retiring from university teaching he returned to the practice of psychiatry. 
With these impeccable credentials, Dr Ausubel was a natural choice to study Maori educational issues. In 1957 he was named Fulbright research scholar to New Zealand, being welcomed by Professor Ernest Beaglehole, head of psychology at Victoria University of Wellington. In 1946 Ernest and Pearl Beaglehole had published Some Modern Maoris, the first systematic study of problems among post-war Maori, but their findings brought little reaction from a complacent public. Beaglehole had thus looked to American foundations for assistance in bringing an eminent scholar to New Zealand to address the disparities between Pakeha and Maori. It was hoped that an outsider's perspective would stimulate an open and reasoned discourse on race relations, in much the same way as Gunnar Myrdal's An American Dilemma had in the United States two decades earlier.

Professor James Ritchie, now emeritus at the University of Waikato, was at that time a junior member of the psychology faculty at Victoria, and was actively engaged in a study of the educational effects of prejudice when Ausubel arrived. He later wrote: 'We had invited him to come and research this matter because we wanted outside confirmation of what we were doing. The New Zealand "knocking machine" was already busy discounting our research before it was even published, and we were left in no doubt that there would be no funding for such purposes again. Still, the Ausubel research gained some public attention, a short-lived minor notoriety.' ${ }^{11}$ Ritchie elaborated on this research, recalling that, 'our work at Victoria was hypothesizing that for a variety of reasons Maori need for achievement was generally low. He did not come here to study ethnic relations at all. But what his research revealed was that Maori need for achievement empirically tested with David McClelland's measure was not noticeably deficient, and that there had to be other reasons why Maori educational attainment was so low. The answer had to be in the historical effects of colonialism. He then framed his own response largely in terms of his American experience since he knew next to nothing of the actual history of ethnic culture clash over the colonial history [in New Zealand].'12

Ritchie, who married the Beagleholes' daughter, was assigned as Ausubel's liaison during his stay in the country. That placed the young New Zealander in a position to observe the American professor. 'He had a sharp eye for grievance and insult towards others and a sense of social honesty and directness that was bound to cause difficulty in a society so unready for confrontation as this was. New Zealanders then disliked any person or cause that might create difficulties . . . New Zealand did not want to hear his message. There was considerable sensitivity to social criticism, especially from overseas visitors who dared to penetrate the popular myth of this "Pacific Paradise," the "social laboratory of the world" and so forth."

Ausubel's article on Maori-Pakeha relations that appeared in Landfall in 1958 was a harbinger of things to come. Founded in 1947 by Charles Brasch 
and Denis Glover, Landfall was New Zealand's first professional journal of literature, the arts and, to a lesser degree, affairs. 'Race Relations in New Zealand, Maori \& Pakeha: an American View' was its first article on race relations. ${ }^{14}$ It contained many of the elements found in Ausubel's later work, but surprisingly drew relatively little comment from readers given that Landfall at the time reached a small elite audience of intellectuals and academics that might be expected to react to a disquieting analysis of their society. The real firestorm of reaction followed release of The Fern and the Tiki by Australian publisher Angus and Robertson two years later, in 1960. Holt, Rinehart and Winston brought out an American edition in 1965.

Ausubel's avowed intent was to produce a treatise on the national character of New Zealand. It was 'an attempt to describe certain salient aspects of the New Zealander that define him as a person'. ${ }^{15}$ As a social scientist and an outsider he felt that he could be more objective and systematic in his inquiry than someone native-born, but he also realised that 'the visiting scholar who proposes to speak his mind forthrightly, . . . must be prepared for many unanticipated and personally distasteful reactions from his hosts'. ${ }^{16}$ Nevertheless, he felt an obligation to make the attempt since the exchange of professional experience in the solution of mutual problems was envisioned as one of the principal aims and potential benefits of the Fulbright programme. His book's first five chapters therefore exposed what he perceived to be the basic contradictions of New Zealand society.

First, Ausubel suggested that the way New Zealanders perceived themselves was at almost total variance with his own views on their personality and behaviour. New Zealanders saw themselves as reflecting the best traits of their British forebears in being reserved, unsentimental, and given to understatement, while at the same time disavowing British snobbishness and arrogance. They thought of themselves as amiable, egalitarian, hospitable, forthright, practical and pragmatic; they were also sports-minded, loved the outdoors, and were capable of 'roughing it'. While admitting that all national self-images were part truth and part myth, Ausubel viewed the New Zealanders as being less reserved than the English but more introverted in relationships than Americans. He felt they were suspicious of strangers and tended to resent foreigners, especially Americans. This he attributed in part to national insecurity and jealousy of a larger, more powerful nation, but also partially to some lingering resentment of American servicemen stationed in New Zealand during World War Two. Ausubel claimed to have been uncomfortable in many homes, feeling himself held personally responsible for assumed shortcomings of American society, the nation's policies, and especially race relations. In a statement bound to rankle with Pakeha New Zealanders of the period he noted that he had had precisely the opposite feeling about my "visits to most Maori homes. The essential difference 
between Maori and Pakeha in this respect inheres in the relative cultural importance attached to the responsibility of being a good host. ${ }^{17}$

New Zealanders were found to have an 'acute sensitivity to and exaggerated defensiveness about any criticism, explicit or implied, from an overseas visitor. ${ }^{18}$ Not only did Ausubel receive criticism from private citizens and the media about his findings, but unexpectedly from professional colleagues as well. He attributed this in part to the authoritarianism and homogeneous value system of the country. With respect to the ideological egalitarianism of the nation, he wrote: 'For most New Zealanders the feeling that social classes should not exist is sufficient evidence for believing that social classes do not exist' ${ }^{19} \mathrm{He}$ proceeded to identify instances of class-consciousness among elites and working groups alike. Moreover, he asserted New Zealanders displayed an attitude of 'smug superiority', erroneously assuming that they were a cut above Americans in matters of public taste, public health, and standard of living - all of which Ausubel robustly disputed.

The 'Welfare State principle', it was suggested, had contributed to the loss of efficiency, ambition and enterprise among New Zealanders: 'This principle was in part a manifestation and instrumental outgrowth of the egalitarian ideal that cast a shadow on the respectability of occupational achievement and established an undifferentiated scale of rewards for effort and ability ... Thus the common floor also tended to constitute a common ceiling, ${ }^{20}$ This had a stultifying effect on the vocational ambitions of youth and adults alike. As a result, Ausubel thought the New Zealander's obsession with drinking, Rugby football and horse racing was transference of the energy, enthusiasm and excitement formerly directed into vocational life and the challenge of the frontier. 'But when people become less concerned about the outcome of the real battle of life, that is, about vocational achievement and personal self-fulfilment, the game itself becomes the real battleground rather than just a dramatic representation of it. ${ }^{21}$

The respective roles of men and women came under Ausubel's scrutiny as well. Although it was a society in which men controlled the power, wealth, public affairs and destiny of the nation, 'of the two sexes women have much the stronger personalities in New Zealand, and in areas where the interests of men and women converge - in home, family, and children - their influence is easily the more dominant'. ${ }^{22}$ While the personalities of men had changed as a result of social, economic and political shifts within New Zealand society, women literally remained homemakers and their personalities had changed little from those of the mid-Victorian pioneers. He then added an observation guaranteed to irritate a sizeable portion of the population: 'By American standards women in New Zealand give the 
impression of being somewhat hard, determined, and lacking in feminine charm and softness'. ${ }^{23}$ He found that negative attitudes in New Zealand toward co-education at the secondary level afforded further proof of the mid-Victorian puritanical ideology that still prevailed within the country regarding sex.

As a psychologist, Ausubel reserved his most devastating criticism for the New Zealand methods of child rearing and discipline. He struggled to understand how a society that professed to be so radically egalitarian and humane adhered to such a Victorian system of discipline, especially the use of corporal punishment. While in the United States there were disparities in how parents from different social classes disciplined their children, 'not only do these social class differences tend to be absent in New Zealand, but prevailing child rearing practices also tend to approximate the lower rather than the middle-class standard in the United States'. ${ }^{24}$ Ausubel discerned a much more formal relationship between parent and child in New Zealand. The secondary schools, along with the family, were found to be the last strongholds of traditional authoritarian discipline in a society that was otherwise radically egalitarian. The secondary schools were traditionbound and hierarchically organised institutions in which the authority of the administrative head was absolute. They embodied the last remnant of Spartan frontier virtues that were rapidly disappearing from New Zealand life. Ausubel seemed shocked that his specific suggestions for reforming these institutions were greeted with 'a torrent of defensive and name-calling reactions in New Zealand, not only from the press and general public but also from headmasters and teachers in post-primary schools'. ${ }^{25}$ His ideas for dealing with defiance among delinquent youth met with equal hostility.

In his final two chapters Ausubel presented an indictment of New Zealand race relations. 'The most striking impression an American receives of race relations in New Zealand is that although they are generally much better than in the United States, they are not nearly as good as people think or claim they are. ${ }^{26}$ Most New Zealanders had had little or no interaction with Maori until the post-war migration to cities, and it was this separation of the races that had fostered an impression of racial harmony. However, the urbanisation of Maori had led to closer contact with Pakeha, this in turn leading to more overt racism. His informants included a large number of Pakeha, Maori and interracial couples who recounted the discrimination they had encountered. Ausubel also observed that many extreme anti-Maori Pakeha, assuming all Americans were racially bigoted, threw caution to the winds, 'emitting a tirade of venom and abuse that made the position of most American segregationists seem moderate by comparison'. ${ }^{27}$

Ausubel recalled the horror with which New Zealand professional colleagues greeted his findings and the plans to publish them. They 
attempted to persuade him that he would be committing professional suicide: the tempest of emotional outbursts and defensive reactions would preclude a rational and constructive approach to the problem. He countered that he had no professional ambitions in the Antipodes; moreover, there were no on-going programmes to improve race relations because 'nobody in Government or professional life was willing publicly to concede that a problem of race relations existed in New Zealand'. ${ }^{28}$ Several times Ausubel reiterated that, while the racial situation in New Zealand was certainly not bad by comparison to the United States and many other parts of the world, what disturbed him most was "not the actual seriousness of the situation but the national self-delusion which blocks recognition of the existence of a problem and thereby renders impossible the adoption of appropriate preventive and remedial measures'. ${ }^{29}$

Glancing into the future, the American scholar predicted that 'Maoripakeha relations will gradually deteriorate until a series of minor explosions will compel the adoption of preventive and remedial measures . . . This situation will intensify Maori racial nationalism and eventually compel Maori leaders to dig their heads out of the sand and organise a self-protective movement similar to that of the National Association for the Advancement of Colored People in the United States. ${ }^{30}$ In this Ausubel correctly foresaw the mounting pressures that led to the 'Maori Renaissance' of the 1970s. The renewed emphasis on old cultural values, especially language, and a growing rate of intermarriage over succeeding decades, rendered Ausubel less accurate in predicting that 'increasing urbanization and the disruption of Maori village life will hasten the Europeanization of the Maori and the decline of traditional values and practices in Maori culture; but the strong colour feelings of the pakeha will prevent any fusion of the two races into one people. For many generations to come the Maoris will constitute a distinct racial-ethnic minority group in New Zealand. ${ }^{31}$ Indeed, Maori remain a distinct racial and ethnic minority, but more on their own terms than the American scholar was able to foresee.

Newspaper reviewers were highly incensed by Ausubel's criticisms of Kiwi culture; although for the most part reviewers acknowledged that his racial findings were important and should not be dismissed. A few examples provide the flavour of these responses. The Hawkes Bay Herald Tribune headlined 'American Professor Dissects NZ and its Way of Life,' following up with, 'No people in the world, no Yahoos dreamed of by a modern Gulliver, could be quite so frightful as the New Zealanders portrayed by Dr David P. Ausubel, a 41-year-old American Fulbright professor from Illinois, in "The Fern and the Tiki.", 32 The writer saw little point in trying to appraise the book in normal review terms, finding its literary style 'prosaic' and the documentation 'nil'. The Southland News noted that 
the book had already been reviewed in almost every paper, magazine and broadcasting programme available to such comment, but it was still not easy to decide what to say about it. After a discussion sympathetic to the American's critique of educational practices in New Zealand, the review concluded: 'The author has a long section on race relations and colour bar, and it is obvious that few New Zealanders could teach him much about the subject; he has been too acute an observer. Such a book as this ought to be closely read. ${ }^{33}$ The National Party newspaper Freedom labelled Ausubel's work 'supercilious', suggesting that his wholesale condemnation of New Zealand society by American standards had 'coloured, if not soured, his outlook and jaundiced his critical faculties' ${ }^{34}$ A strong defence of the prevailing race relations mythology followed. Yet after noting that Ausubel believed New Zealanders were unwilling to come to grips with racial issues, the review found: 'He does give valid reasons which should jolt New Zealanders out of their complacency. The chapters on this subject are worthy of the closest study, even where the reader may disagree with the author. One thing this book will do is that it will make people think. ${ }^{35}$

By far the most impassioned defence of New Zealand honour came from Pat Lawlor in the middle-of-the-road national weekly New Zealand Free Lance under the headline 'A Tattered Fern and a Tainted Tiki'. ${ }^{36}$ Couched in terms of New Zealand on trial, with Ausubel as prosecutor and Lawlor for the defence, it opened with a well-poisoning statement: 'Plainly, the learned professor did not like us'. ${ }^{37}$ Lawlor then quickly leapt to the defence of racial hegemony. 'One aspect of the book will be resented - that is the unwarranted and unwise attempt to create in the minds of people at home and abroad the impression that there is brewing here a colour problem of comparative Little Rock dimensions . . . This, I feel, is untrue and unjust and may give rise to series [sic] dissension. The professor is correct only in the minor aspect of a problem, openly admitted and discussed by Maori and Pakeha alike, that the issue is a social and not a racial one. ${ }^{38}$ The long review, less inclined than others to accept his findings on race relations, then devoted itself to castigating his criticism of the New Zealand national character.

Philip Smithells' review for Landfall was perhaps the most caustic, he asserting that if Ausubel had merely expanded his 1958 Landfall article on race relations in New Zealand the book would have been valuable. 'As it is he has attempted too much. Some of the time he is well on target - part of it badly awry. ${ }^{39} \mathrm{He}$ confided: 'I can never remember being provoked to make so many marginal notes of disagreement in any book I have read - but let it be summarized by saying that although he sometimes observed facts and attitudes correctly, he shows little sign of understanding the direction or rate of change. ${ }^{40}$ Smithells, however, was impressed with the 
two chapters on race relations, arguing that all New Zealanders should read them. He noted wryly that 'Dr Ausubel felt himself welcome among Maoris and this is a very good thing. Perhaps if his rapport with Pakehas had been better so would his investigations have been more successful and his interpretations less choleric. ${ }^{41}$ In summation, Smithells found The Fern and the Tiki an uneven and disappointing book and he was not sure for whom it was intended. ${ }^{42}$ This viewpoint is congruent with current assessments of Ausubel's impact on New Zealand some four decades ago. If he had limited himself to Maori-Pakeha relationships, and not risked insulting New Zealanders' culture, his work would have been better received.

Academic critics were more measured in their responses. In Fretful Sleepers and Other Essays, novelist and critic Bill Pearson devoted a chapter to Ausubel's ideas, drawing from his own earlier review of The Fern and the Tiki. ${ }^{43}$ Pearson's critique was in two sections. First he examined the American's analysis of the New Zealand character, finding it seriously lacking. Pearson was quick to point out that Ausubel was not the first to identify the contradictions in New Zealand society; indeed he had done so himself in his original 'Fretful Sleepers' article, published in Landfall in 1952. There was also an essay by C.M. Chapman that should have been noted. Pearson believed that if this literature had been consulted Ausubel 'might have been able to detect blind spots in the assumptions of native critics and advanced the criticism a stage further. He might also have found clues to the discrepancies in national behaviour that could have saved him from some of the more unfortunate errors into which he is led by his assumption that he is the first in the field. ${ }^{44}$ Pearson thought the American had been 'too quick off the press' with his findings and had insufficiently tested them against further data from the field. In short, Ausubel had spent too little time in New Zealand to find deeper explanations for the issues he had raised.

Like most critics, Pearson found the best part of the book to be the two chapters on race relations, recommending that they 'should be read and considered by every New Zealander who believes or professes to believe that racial equality is one of the fundamental premises of the New Zealand social code. Dr Ausubel makes a prediction that "as long as New Zealanders persist in deluding themselves that all is well in the sphere of race relations, the only realistic prospect for the future is the emergence of a brown proletariat segregated in the urban slums and living in a state of chronic tension with their white neighbours." The prediction may strike us as far fetched but, since we have been warned, we have only ourselves to blame if it should turn out to be true. ${ }^{45}$ In the final analysis Pearson believed Ausubel to have produced a book containing 'both a criticism of New Zealand Pakeha attitudes, which needs sifting of his own prejudices and 
hasty conclusions, and a survey of race relations that is valuable and unique'. ${ }^{46}$

John Pocock, writing in the New Zealand Listener, found that Ausubel's unflattering impressions of the national character had provoked many people in New Zealand and that his book had received a great deal of unfavourable publicity as a result. ${ }^{47} \mathrm{He}$ observed that this was ironic since only about one-fifth of Ausubel's book dealt with New Zealanders' intolerance of criticism. 'The trouble', he noted, 'does not lie in Professor Ausubel's judgements, which are those of plenty of other people, but in the fact that too many of them are not substantiated with the degree of rigour we should be able to expect of a scientist and scholar . . That is why he annoys people; he annoys them because he does not illuminate them. ${ }^{48}$ The lack of illumination is suggested at the very outset of the review, Pocock admitting that 'Professor Ausubel's book - by the way, I have tried to find a symbolic meaning in the title, but without success - is not an easy one to review'. ${ }^{49}$ Incidentally, the title's symbolism eluded all subsequent reviewers as well.

W.L. (Bill) Renwick, then an official in the Department of Education, reviewed The Fern and the Tiki for the professional journal Nga Pukapuka. ${ }^{50} \mathrm{He}$ believed the book's 'fatal weakness' was that, while the author had attempted a treatise on the national character of New Zealanders, 'on almost every one of the first 148 pages of his book Dr Ausubel demonstrates his lack of qualifications for writing such a book. Indeed, it is one of the unsolved mysteries of his work that he can write so much about the methods of scholarship and practice them so little. ${ }^{51}$ Not surprisingly, Renwick found this lack of scholarly rigour most objectionable in those sections of the book criticising New Zealand educational practices. 'In failing to support his hypothesis and assertions with research data that can be inspected, tested again, and then either accepted or found wanting, the critic does a disservice both to the behavioural science of which he is a practitioner and the cause of more humane relations of which he is champion. ${ }^{52}$ Like other reviewers, however, Renwick had high regard for the chapters on race relations, finding that 'here he has much better control over his material than he does elsewhere in the book and he has much of value to say about our race relations. ${ }^{, 53}$

Renwick's appears to be a common criticism. More recently James Ritchie comments that Ausubel's work was 'not an empirical study but an anecdotal account of his experiences here, picking on isolated incidents and generalizing from them ... This is not to diminish the statement which the book makes. But it does explain the dismissive response his work received from intellectual and academic readers . . . In fact, the F\&T was not at all widely read. Everyone we spoke to about it had an opinion, 
but few had read it . . Then it disappeared without trace - remaindered in the bookshops and rarely cited in the literature until very recently. ${ }^{54}$

Ausubel's lesser known second work arising out of the same research nexus, Maori Youth. A Psychoethnological Study of Cultural Deprivation, was generally well-received, in part because it was less confrontational and had a clear research design. ${ }^{55}$ The American edition carried a foreword by Ernest Beaglehole indicating that Ausubel's work fitted very aptly into the pattern of Maori investigations sponsored by Victoria University: 'This study therefore can be read both as a contribution to the theory of psychological acculturation and as a blue-print for action by teachers and administrators and others concerned with the difficulties of Maori young people'. ${ }^{56}$ The book was published with a substantial contribution from the Maori Purposes Fund Board. However, according to Ritchie in 2000, "neither book became the "blueprint for action" that Beaglehole was seeking and the real wake-up call came not from academia but from direct action by Maori themselves a decade later. There was no written constitution to reveal the dilemma here that was to fire the civil rights movement in the USA; no way to break through to challenge denial as was the case with Rosa Parks and the sit-ins in Alabama; no students riding buses into the bastions of discrimination. New Zealanders had created their own reality by simply claiming the "best race relations in the world". And, do you know, no one has ever asked me to comment on Ausubel and his work till this request! The reality may not have been as bad or as blatant as he reported; that is not for a pakeha to say. Maybe he can be accused of overstatement but at least a statement was made. ${ }^{57}$

One must be cautious about accepting Professor Ritchie's analysis uncritically. His close association with Maori causes - working primarily with the Tainui people - for nearly four decades has led him to assert that it was the Maori themselves who engineered the great revival of the 1970s. He is little inclined to give any credit to Pakeha intellectuals or politicians. Moreover, Ritchie's recollections of Ausubel's work are filtered from forty years distance. Obviously The Fern and the Tiki did not have an immediate effect on New Zealand society - even liberal New Zealanders had little choice but to defend their cultural values. However, it arguably became a delayed action intellectual bomb that exploded into the political activism of the next generation.

As an outsider, Ausubel drew unwelcome attention to racial relationships in New Zealand. A strong Kiwi response could therefore have been expected. Robin Winks had been the first American Fulbright scholar to publish a lengthy critique of New Zealand society, although his criticisms were relatively mild compared to those of Ausubel. In his book These New Zealanders, published in 1954, Winks recorded that 'New Zealanders do 
not like to be criticized', although he later moderated some of his views and took refuge in the fact that he had married a Kiwi woman. ${ }^{58}$ Perhaps Ausubel should have heeded his fellow American's warning. Ausubel's work also raised the issue of how far a Fulbright scholar should go in criticising the institutions of the host country. Was unbounded academic freedom inimical to being a good representative of the United States abroad? Certainly Ritchie believes that Ausubel's work stretched the boundaries on this issue. Things came to a head in what the former refers to as 'the Broadcasting Affair.' He recalls that Ausubel had been invited to give a series of talks on NBC, but these were cancelled after the American scholar attacked New Zealand's denial of the existence of prejudice and the unexamined state of race relations in a speech to the Social Sciences Section of the Royal Society of New Zealand. After the press reported the speech, the NBC, after contact with the US Embassy, withdrew its invitation. The Fulbright Foundation then reportedly informed Ausubel that the purpose of the Fulbright scheme was to foster good relations with the host country and that he was in violation of his contract. ${ }^{59}$

Although Ritchie's account of 'the Broadcasting Affair' has not been independently corroborated, Ausubel himself noted the problems that an overseas visitor could expect from the media: 'Sooner or later, if he happens to be a social scientist, he is asked by the newspapers, by the New Zealand Broadcasting Service, and by various professional societies and Government departments to express his views on some issues of current public concern; and assuming that the same standards and conventions prevail about such matters as in other countries, and feeling under some obligation to further the avowed purposes of the international exchange programme, he usually accedes to these requests. If his considered opinions are not in accord with those that are generally accepted, however, he soon finds himself the storm centre of an acrimonious controversy and the target of much emotional comment and resentful name calling. ${ }^{60}$

There is no record of such an incident in the Fulbright Board Minutes from the period, only an entry that in April 1958 the American scholar was granted a two-month extension of time to complete his work. ${ }^{61}$ Nonetheless, it is unlikely that the Fulbright Board members could have been pleased when Ausubel wrote the following: 'The Fulbright Programme was established by the United States Government with the express purpose of "increasing mutual understanding between the people of the United States and the people of other countries." ... However it does not specify how this ambitious goal may be best implemented. This matter is presumably left to the judgement of and discretion of the individuals operating in the Programme. One optimistic approach to the problem of international public relations is based on the rather naïve premise that increased contact in and 
of itself fosters goodwill amongst different nationality groups. Unfortunately, however, although these results are sometimes forthcoming, the weight of the evidence indicates that when people from different cultural backgrounds are brought into more intimate contact, they are more likely both to confirm their original prejudices and to develop new reasons for disliking each other ... Neither does the exchange of professional views and information necessarily increase mutual understanding ... Since American social and political institutions are not highly respected in New Zealand, American social scientists - psychologists, psychiatrists, sociologists, political scientists, educationists - tend to be viewed with distrust and suspicion. This basic distrust, when added to the general hypersensitivity of New Zealanders to any criticism of their own institutions, does not create a propitious atmosphere for frank and dispassionate exchange of views. ${ }^{62}$

Recently Bill Renwick, recalling his 1960 review of The Fern and the Tiki, somewhat facetiously suggested that perhaps Ausubel thought Winks had not been tough enough on New Zealanders and was making up for it! But this is not altogether convincing since there is no indication Ausubel was even familiar with Winks' work. Renwick of course was one of those New Zealand intellectuals who pointed out perceived shortcomings in Ausubel's research, dismissing it as being too flawed to be taken seriously. However, he is now willing to concede the possibility that Ausubel's greatest impact was indeed on the next generation rather than his own.

Ausubel's caustic assessment of the established New Zealand social order nearly obscured the importance of his message. Even so, virtually all critics, then and since, have agreed that he had something very important to say about life in the Antipodes. Later, during a mid-1986 conference on US-New Zealand relations, it was noted that some of the American's predictions had an uncanny prescience. According to The Evening Post, 'Ausubel might have been an unpopular man but . . he was, as an American might say, damn right when it came to predicting New Zealand's future. He wrote sometime in 1959 "the honeymoon of prosperously muddling through while recklessly violating every known principle of economics is over." And, "over the long haul the economic crisis will progressively deepen until New Zealanders are finally willing to face up to one inescapable reality of economic life, namely, that to stay in business one must be able to compete effectively in a competitive world market." His prescription for change in our economy might be mistaken for an agenda of the national economic debate of the last ten years. Ausubel was hardly less accurate in his prediction for the course of New Zealand race relations. ${ }^{63}$ One can only assume that Ausubel would be gratified to learn that his work has finally been accorded serious recognition. 
When asked by the present writer to comment on this paper Dr Ausubel submitted the following formal response:

'First, I wish to commend Professor Kersey for the admirably complete, accurate and excellently expressed summary of my views in The Fern and the Tiki regarding the national character, social attitudes and race relations of the people of New Zealand . . . as far as I can judge from the quotations cited here, from both prominent Pakehas and Maoris, my characterization of New Zealand race relations as generally poor (but mythologically thought otherwise by most New Zealanders) is the only aspect of my book's findings that was found to be acceptably veridical and reasonably true to experienced fact by the New Zealand readers of my book - with, of course, the possible exception of young university students. This was the reality of the situation, first in 1960 and again at the start of the new millennium, as the more recent data conclusively demonstrated.

My informal research finds reported in The Fern and the Tiki were admittedly impressionistic, as most empirical studies of national character are (e.g., Barzini's classical and deservedly famous The Italians) but the specific research project for which I received the Fulbright Research Award, that reported in great detail in Maori Youth, but which none of the critics even mentioned, conformed to all of the recognized, scientifically rigorous methodological standards found in comparable psychoethnological studies.

Last, I wish to lay to rest, if I can, the argument a visitor encounters perennially and continually in all quarters of New Zealand, namely, "But how can you claim to perceive, understand, and interpret the attitudes that New Zealanders manifest about any controversial issue when you can interact first-hand with so few people in the course of only one year's residence and usually with just a single class of unrepresentative people, i.e., intellectuals and political and religious deviants, etc." You also tend to associate mostly with comparable New Zealand intellectuals coming from an educated class of professionals and university graduates who obviously constitute a skewed and unrepresentative population. Finally, as a foreign visitor you are much more aware of differences from yourself attitudinally than are natives who have been exposed to these same differences and blindspots for the better part of a lifetime.

It is true, of course, that prolonged residence in a foreign country tends to counteract extreme impressions received from chance encounters with very forceful but unrepresentative natives; but the longer one resides in this foreign country the less open and sensitive one generally becomes to environmental, interpersonal, and institutional differences until one begins to think like the natives and to develop the same blindspots 
oneself that they have as a result of long-term and continual exposure (i.e. by a process of sensitization). ${ }^{64}$

As Ausubel suggests, The Fern and the Tiki arguably had its greatest impact on Maori and Pakeha who were to become national leaders. There is a line of reasoning which holds that at key points in history the inexorable forces demanding human rights and political self-determination for minorities and indigenous peoples have been recognised, accepted (perhaps grudgingly), and facilitated by receptive figures in the dominant culture. In the United States this took the form of Lyndon Johnson's accommodation with Civil Rights leaders such as Martin Luther King. In South Africa it was F.W. DeKlerk's freeing of Nelson Mandela in hopes of building a new bi-racial society. In New Zealand during the 1970s and 1980s it was Pakeha politicians like Norman Kirk and, if possibly unwittingly and under pressure, Geoffrey Palmer who seized the moment to advance, within limits to be sure, Maori aspirations. In co-operation with Maori leaders such as Matiu Rata, Koro Wetere, and Edward Durie they established the Waitangi Tribunal, then expanded its role as a formidable venue for hearing Treaty grievances, thus opening the way for eventual reconciliation between New Zealand's two major cultures.

Despite the furore surrounding David P. Ausubel's writings nearly a half-century ago, his message had resonance for a generation of New Zealanders of both races that looked to a future of justice and bicultural harmony. ${ }^{65}$ Thus it is now generally acknowledged that The Fern and the Tiki will be remembered as the provocative little book that played a limited but significant role - alongside Dame Whina Cooper's land march, the occupation of Bastion Point, and the Springbok Tour protests - in forever changing the social and political landscape of Aotearoa-New Zealand.

1 David P. Ausubel, The Fern and the Tiki, an American View of New Zealand: National Character, Social Attitudes and Race Relations, New York, 1965. First published in Sydney by Angus and Robertson, 1961.

2 Interview with Sir Geoffrey Palmer, 13 March 2000. Tape OHInt-0475/01, National Library of New Zealand, Wellington.

3 Interview with Moana Jackson, 8 June 2000. Tape OHInt-0475/04, National Library of New Zealand, Wellington.

4 David Pearson, A Dream Deferred: The Origin of Ethnic Conflict in New Zealand, Wellington, 1990, p.1.

5 Augie Fleras and Paul Spoonley, Recalling Aotearoa: Indigenous Politics and Ethnic Relations in New Zealand, Auckland, 1999, p.4.

6 E.T. Durie, 'The Treaty in Maori History,' in William Renwick (ed), Sovereignty \& Indigenous Rights: The Treaty of Waitangi in International Contexts, Wellington, 1991, p.161.

7 Jim Barr and Mary Barr, Working Titles, Books that Shaped New Zealand, Wellington, 1993, p.1. 


\section{Opening a Discourse on Race Relations in New Zealand}

8 Conversation with Philip Rainer, Assistant Head Librarian, Alexander Turnbull Library/ National Library of New Zealand, Wellington, 2000.

9 James Belich, The Maori Wars and the Victorian Interpretation of Racial Conflict, Auckland, 1986, chpt. 15.

10 Frederick Ohles, Shirley M. Ohles, and John G. Ramsay, Biographical Dictionary of Modern American Educators, Westport CT, 1997, pp.11-12. Author information from the dust jacket of Maori Youth. See also Directory of the American Psychological Association, New York, 1993; Who's Who in American Jewry, New York, 1972.

11 James Ritchie, Becoming Bicultural, Wellington, 1992, pp.194-95.

12 Correspondence with Dr James Ritchie, 20 May 2000.

13 Ibid.

14 David P. Ausubel, 'Race Relations in New Zealand, Maori \& Pakeha: an American View,' Landfall, vol.. 12, no. 3, September 1958, pp.233-47. See W. H. Oliver, 'The Awakening Imagination,' in Geoffrey W. Rice, (ed), The Oxford History of New Zealand, 2nd ed, Auckland, 1992, p.555.

15 Ausubel, The Fern and the Tiki, p.1.

16 Ibid., p.4.

17 Ibid., p.15.

18 Ibid., p.23.

19 Ibid., pp.31-32.

20 Ibid., p.42.

21 Ibid., p.51.

22 Ibid., p.77.

23 Ibid., p.79.

24 Ibid., p.87.

25 Ibid., p.93.

26 Ibid., p.149.

27 Ibid., p.153.

28 Ibid.

29 Ibid., pp.155-56.

30 Ibid., pp.229-30.

31 Ibid., p.230.

32 Hawkes Bay Herald Tribune, 26 March 1960, National Library of New Zealand Collection of Reviews on The Fern and the Tiki, p.1.

33 Southland News, 4 June 1960. Collection of Reviews, p.6.

34 Freedom, 18 April 1960. Collection of Reviews, p.7.

35 Ibid., p.8.

36 New Zealand Free Lance, 6 April 1960. Collection of Reviews, p.9.

37 Ibid.

38 Ibid.

39 Philip Smithells, 'Review of the Fern and the Tiki,' Landfall, vol.. 2, no. 8, June 1960, p.205.

40 Ibid., p.207.

41 Ibid.

42 Ibid., pp.207-08.

43 Bill Pearson, 'An American Looks at New Zealand,' in Fretful Sleepers and Other Essays, Auckland, 1974, pp.85-93.

44 Ibid., p.86.

45 Ibid., p.92.

46 Ibid., p.93.

47 John Pocock, The New Zealand Listener, 6 May 1960, pp.4-5. 


\section{Journal of New Zealand Studies}

48 Ibid., p.4.

49 Ibid.

50 Bill Renwick, Review in Nga Pukapuka/Reviews, Notes and Other Items, Dept. of Education, vol.. 16, nos. 11-12, November-December 1960, pp.296-99.

51 Ibid., p.298.

52 Ibid.

53 Ibid

54 Ritchie correspondence, 20 May 2000.

55 David P. Ausubel, Maori Youth. A Psychoethnological Study of Cultural Deprivation, Victoria University of Wellington Publication in Psychology number 14, Wellington, 1961. Favourable reviews appeared in the Otago Daily Times, 20 May 1961 and the Christchurch Press 13 May 1961.

56 Ibid., Foreword, p.1.

57 Ritchie correspondence, 20 May 2000.

58 Robin Winks, These New Zealanders, Wellington, 1954. Joan Druett, Fulbright in New Zealand, Wellington, 1988, pp.60-62.

59 Ritchie correspondence, 20 May 2000.

60 Ausubel, The Fern and the Tiki, p.23.

61 New Zealand-United States Educational Foundation, Board of Directors Minutes, 19571958. Manuscript Reference 96-089, National Library of New Zealand, Wellington.

62 Ausubel, The Fern and the Tiki, pp.216-17.

63 Roger Mackey, 'Into the NZ-US connection', The Evening Post, 16 July 1986, p.6.

64 Correspondence with Dr David P. Ausubel, 30 January 2001 and subsequent statement.

65 In retirement Dr Ausubel remains an active scholar. His most recent work is The Acquisition and Retention of Knowledge: A Cognitive View, Dordrecht, The Netherlands, 2000. 